\title{
Implementasi Model Pembelajaran Predict Observe Explain Berbasis Drill and Practice Untuk Meningkatkan Keaktifan dan Prestasi Belajar Pada Mata Kuliah Pemindahan Tanah Mekanis
}

\author{
Yelisman Zebua $^{1^{*}}$, Maria Magdalena Zagoto ${ }^{2}$, Oskah Dakhi ${ }^{3}$ \\ ${ }^{1}$ IKIP Gunungsitoli, Sumatera Utara, Indonesia \\ ${ }^{2}$ Universitas Nias Raya, Sumatera Utara, Indonesia \\ ${ }^{3}$ Universitas Nias Raya, Sumatera Utara, Indonesia \\ * Corresponding-Author. Email: yelyszeb@gmail.com
}

Receive: 13/05/2021

Accepted: 23/08/2021

Published: 01/10/2021

\begin{abstract}
Abstrak
Penelitian ini bertujuan untuk meningkatkan keaktifan dan prestasi belajar mahasiswa Program Studi Pendidikan Teknik Bangunan, IKIP Gunungsitoli pada mata kuliah Pemindahan Tanah Mekanis dengan menerapkan model pembelajaran Predict Observe Explain yang dilengkapi dengan Lembar Kerja Mahasiswa berbasis Drill and Practice. Penelitian ini merupakan Penelitian Tindakan Kelas yang dilakukan dalam dua siklus. Subjek penelitian ini adalah mahasiswa semester III sebanyak 30 orang, Tahun Akademik 2019/2020. Data diperoleh melalui wawancara, observasi, tes, dan angket. Teknik analisis data yang digunakan adalah analisis deskriptif. Hasil penelitian menunjukkan bahwa penggunaan model pembelajaran Predict Observe Explain yang dilengkapi dengan Lembar Kerja Mahasiswa berbasis Drill and Practice dapat meningkatkan aktivitas dan prestasi belajar mahasiswa pada mata kuliah Pemindahan Tanah Mekanis. Peningkatan keaktifan terlihat dari peningkatan dari $80 \%$ pada Siklus I dan $86,67 \%$ pada Siklus II. Prestasi belajar mahasiswa dapat di lihat dari aspek sikap, pengetahuan, dan keterampilannya. Berdasarkan hasil tes pada Siklus I, pencapaian aspek sikap pada Siklus I adalah $83,33 \%$ dan meningkat menjadi 93,33\% pada Siklus II. Ketercapaian aspek pengetahuan mahasiswa sebesar $46,67 \%$ dan meningkat menjadi $83,33 \%$ pada Siklus II. Pencapaian aspek keterampilan sebesar $83,33 \%$. Penelitian ini menyimpulkan bahwa penerapan model pembelajaran Predict Observe Explain dilengkapi dengan Lembar Kerja Mahasiswa berbasis Drill and Practice merupakan strategi pengajaran yang tepat dalam penyampaian materi pada mata kuliah Pemindahan Tanah Mekanis untuk memotivasi aktivitas mahasiswa dan meningkatkan prestasi belajar mahasiswa.
\end{abstract}

Kata Kunci: pemindahan tanah mekanis, predict observe explain, drill and practice

\section{Abstract}

This research aims to improve students' activeness and learning achievement of the Building Engineering Education Study Program, IKIP Gunungsitoli, in mechanical land transfer courses by applying the Predict Observe Explain learning model equipped with Drill and Practice-based Student Worksheets. This study is a Class Action Study conducted in two cycles. The subject of this study is a third-semester student of 30 people, Academic Year 2019/2020. Data is obtained through interviews, observations, tests, and questionnaires. The data analysis technique used is descriptive analysis. The results showed that using predict observe explain learning model equipped with Drill and Practicebased Student Worksheets can improve students' learning activities and achievements in Mechanical Land Transfer courses. The increase in liveliness is seen from an increase of $80 \%$ in Cycle I and $86.67 \%$ in Cycle II. Students' learning achievements can be seen from the aspect of attitude, knowledge, and skills. Based on the results of tests on Cycle I, the achievement of attitude aspects in Cycle I is $83.33 \%$ and increases to $93.33 \%$ in Cycle II. The ability of student knowledge aspects by 
46.67\% and increased to $83.33 \%$ in Cycle II. Achievement of skill aspects by $83.33 \%$.. The study concluded that applying the Predict Observe Explain learning model equipped with Drill and Practice-based Student Worksheets is the right teaching strategy in the delivery of materials in Mechanical Land Transfer courses to motivate student activities and improve student learning achievement.

Keywords: mechanical land transfer, predict observe explain, drill and practice

\section{Pendahuluan}

Pendidikan merupakan aspek penting dalam menentukan kualitas dan kelangsungan hidup suatu bangsa. Pendidikan menjadi salah satu indikator kemajuan suatu bangsa. Suatu bangsa akan dianggap maju jika kualitas pendidikannya tinggi. Kualitas pendidikan di Indonesia, yang merupakan negara berkembang, masih tergolong rendah. Oleh karena itu, inovasi dalam dunia pendidikan perlu dilakukan untuk meningkatkan kualitas dari pendidikan agar dapat bersaing dengan negara lain. Pemerintah, dalam hal ini berupaya melakukan perbaikan dalam dunia pendidikan, baik melalui peningkatan kualitas pendidik, peningkatan kualitas sarana prasarana yang menunjang pendidikan, pembaharuan kurikulum dan usaha-usaha lainnya.

Pendidik, dalam melaksanakan tugas dan kewajibannya dalam dunia pendidikan, mempunyai rencana kegiatan yang di atur dalam sebuah kurikulum yang dimana dalam pembelajaran berpusat pada dosen berubah menjadi berpusat pada mahasiswa, pola pembelajaran pasif menjadi pembelajaran aktif mencari, serta pola belajar sendiri menjadi belajar kelompok (Masril, et al., 2020; Fajra, et al., 2020; Rina, et al., 2020) Perubahan pola pembelajaran pasif menjadi pembelajarn aktif mencari semakin diperkuat dengan model pembelajaran pendekatan ilmiah (Zagoto, et al, 2019; Dakhi, et al., 2020). Pembelajaran ini menekankan pada pengamatan, penalaran, penemuan, pengabsahan, dan penjelasan tentang suatu kebenaran.

Sarana dan prasarana yang disediakan kampus telah mengarah pada peningkatan aktivitas belajar mahasiswa dalam mengikuti proses pembelajaran. Salah satunya kampus ini memiliki fasilitas laboratorium yang cukup memadai untuk kegiatan pembelajaran (Fajra, et al., 2020; Zebua, 2020; Zega, et al., 2021), namun penggunaan fasilitas laboratorium ini kurang dimanfaatkan oleh dosen di kampus.

Berdasarkan hasil observasi dan wawancara yang dilakukan dosen hanya terbatas pada penggunaan metode ceramah, tanya jawab dan penugasan sehingga aktivitas mahasiswa hanya terbatas mendengarkan, mencatat penjelasan dosen dan mengerjakan penugasan yang diberikan oleh dosen. Hal ini tentu membuat mahasiswa cenderung pasif atau rendah aktivitasnya dalam pembelajaran karena pembelajaran hanya berpusat pada dosen.

Proses pembelajaran dikatakan baik, bila proses tersebut dapat membangkitkan aktivitas belajar yang efektif (Timor,etal., 2020; Zagoto, et al., 2019). Keaktifan mahasiswa dapat menunjukkan seberapa tertarik mahasiswa dalam mengikuti pembelajaran. Semakin aktif mahasiswa dalam mengikuti pembelajaran maka pembelajaran yang berlangsung akan semakin efektif (Masril, et al., 2020; Telaumbanua, et al., 2021).

Salah satu model pembelajaran yang memancing keaktifan dan melibatkan mahasiswa yaitu model pembelajaran predict observe explain. Model pembelajaran predict observe explain dapat meningkatkan aktivitas dan prestasi belajar mahasiswa (Widyaningrum, R., et al, 2013). Model pembelajaran predict observe explain cocok diterapkan untuk meningkatkan ketertarikan mahasiswa yang berhubungan dengan pembelajaran sains (Udayani, et al, 2016).

Model pembelajaran predict observe explain bertolak dari teori kontruktivisme yang menekankan individu yang diharuskan 
secara aktif membangun pengetahuan dan keterampilannya (Muna, 2017).

Sintaks model pembelajaran predict observe explain secara garis besar adalah prediksi yang dituliskan oleh mahasiswa yang berkaitan dengan praktik lapangan yang akan dilakukan atau didemonstrasikan (predict), pengamatan terhadap kegiatan praktik lapangan atau demonstrasi yang dilakukan (observe), dan yang terakhir mahasiswa mencoba melakukan dekonstruksi hasil demonstrasi atau percobaan dan menjelaskan mengapa hal tersebut terjadi (explain).

Model pembelajaran predict observe explain dapat membuat mahasiswa lebih aktif dalam bertanya dan dapat mengurangi kesalahpahaman mahasiswa dalam menangkap materi (Sumirat, F., 2012). Sehingga mahasiswa juga akan lebih lama dalam mengingat suatu konsep karena melakukan pengamatan langsung.

Selain model pembelajaran, media pembelajaran juga sangat menentukan kualitas dari pembelajaran itu sendiri (Ferdiansyah, Ambiyar, Zagoto, M. M., Putra, I E D., 2020). Salah satu media yang dapat digunakan untuk membantu mahasiswa belajar mandiri dan bisa meningkatkan kemampuan mahasiswa dalam menganalisis soal adalah lembar kerja mahasiswa yang berbasis drill and practice. Drill and practice merupakan suatu teknik yang dapat diartikan sebagai suatu cara mengajar mahasiswa melakukan kegiatan praktek lapangan, mahasiswa memiliki ketangkasan dan keterampilan lebih tinggi dari apa yang dipelajari (Pujawan, 2018). Lembar kerja mahasiswa berbasis drill and practice ini dapat diterapkan pada mata kuliah Pemindahan Tanah Mekanis yang melibatkan soal-soal hitungan analisis harga satuan pekerjaan (AHSP) pekerjaan tanah dan analisis pengendalian kebutuhan waktu pekerjaan tanah yang mana dapat merangsang mahasiswa untuk aktif berpikir, aktif berlatih menyelesaikan soal-soal dan aktif dalam proses pembelajaran. Karena pada dasarnya dengan latihan soal lebih banyak, jika menemui kesulitan mahasiswa akan cenderung bertanya agar bisa paham.

Dari konteks uraian di atas, untuk mengetahui motivasi keaktifan mahasiswa serta prestasi dan hasil belajar mahasiswa, maka sebuah pengimplementasian model pembelajaran predict observe explain berbasis drill and practice untuk meningkatkan keaktifan dan prestasi belajar pada mata kuliah Pemindahan Tanah Mekanis.

\section{Metode}

Penelitian ini merupakan Penelitian Tindakan Kelas yang dilaksanakan dalam dua siklus. Setiap siklusnya terdapat empat tahapan, yaitu perencanaan, pelaksanaan, observasi, dan refleksi. Subjek penelitian adalah mahasiswa semester III prodi Pendidikan Teknik Bangunan, IKIP Gunungsitoli, tahun akademik 2019/2020. Pemilihan subjek dalam penelitian ini didasarkan pada hasil observasi yang dilakukan pada saat pra-siklus, di mana subjek yang di pilih tersebut teridentifikasi mempunyai permasalahan dalam pembelajaran yaitu keaktifan dan prestasi belajar yang rendah.

Data yang dikumpulkan meliputi data tentang keadaan mahasiswa yang berupa data kualitatif dan kuantitatif. Data kualitatif diperoleh dari hasil observasi, angket keaktifan, angket sikap, dan wawancara. Data kuantitatif di dapat dari hasil penilaian prestasi belajar mahasiswa pada materi Pemindahan Tanah Mekanis yang meliputi aspek sikap, pengetahuan, dan keterampilan baik pada siklus I maupun siklus II.

Teknik analisis data pada penelitian ini menggunakan analisis deskriptif. Analisis data menggunakan tiga tahap yaitu reduksi data (pengelolaan data), penyajian data (mengorganisasikan data kedalam suatu bentuk tertentu sehingga datanya terlihat lebih utuh), dan triangulasi atau pemeriksaan keabsahan data dengan memanfaatkan sesuatu yang lain di luar data tersebut sebagai pembanding data (Sugiyono, 2018)

\section{Hasil dan Pembahasan \\ Hasil}


Penelitian tindakan kelas ini bertujuan untuk meningkatkan keaktifan dan prestasi belajar mahasiswa semester III prodi Pendidikan Teknik Bangunan, IKIP Gunungsitoli, tahun akademik 2019/2020 pada mata kuliah Pemindahan Tanah Mekanis dengan menerapkan model pembelajaran predict observe explain dilengkapi dengan lembar kerja mahasiswa berbasis drill and practice. Keaktifan mahasiswa dalam proses pembelajaran meliputi visual activity, oral activity, listening activity, dan writing activity.

Prestasi belajar yang di ukur meliputi aspek sikap, pengetahuan, dan keterampilan. Penelitian ini dilakukan dalam 2 siklus yaitu siklus I dan siklus II. Masing-masing siklus terdiri dari tahap perencanaan, tahap pelaksanaan tindakan, tahap pengamatan dan tahap refleksi.

Proses pembelajaran menggunakan model predict observe explain dilakukan dalam kelompok untuk memberikan esempatan kepada mahasiswa untuk bekerjasama, jujur, tanggung jawab dan disiplin dalam kelompoknya.

\section{Siklus I}

\section{a. Perencanaan}

Pada tahap perencanaan siklus I dilakukan penyusunan silabus, RPS, LKM, instrumen penilaian keaktifan mahasiswa, serta instrumen prestasi belajar. Berdasarkan data silabus diketahui bahwa materi Pemindahan Tanah Mekanis memiliki alokasi waktu 2 SKS. Perincian pembelajaran pada siklus I yaitu 1 SKS (1 x 50 menit) untuk penyampaian materi dan 1 SKS (1 x 50 menit) untuk evaluasi siklus I.

\section{b. Pelaksanaan}

Tahap pelaksanaan siklus I terdiri atas 4 kali pertemuan, dengan 3 kali pertemuan untuk penyampaian materi dan 1 kali pertemuan untuk evaluasi siklus I. Pada pertemuan awal ini dilakukan kegitan praktik lapangan untuk penilaian aspek keterampilan mahasiswa.

Praktik lapangan diawali dengan dosen memberikan apersepsi dan menjelaskan tujuan serta model pembelajaran yang akan dilakukan hari ini, lalu dosen menjelaskan materi yang akan dipelajari secara singkat dan memberikan lembar prediksi kepada masing-masing mahasiswa.

Mahasiswa menuliskan tentang prediksinya mengenai permasalahan yang ada pada lembar prediksi dan dikumpulkan kepada dosen, setelah itu mahasiswa memulai kegiatan praktik. Praktik di tutup dengan salah satu kelompok maju untuk mempresentasikan hasil praktikumnya.

Setelah selesai praktik lapaangan, mahasiswa diharuskan menulis laporan hasil praktik kelompoknya masing-masing. Pertemuan kedua dan ketiga hampir sama dengan pertemuan pertama, hanya saja pada pertemuan kedua dan ketiga tidak ada praktik lapangan dan mahasiswa belajar materi di kelas.

Pada pertemuan terakhir atau pertemuan keempat, dilaksanakan evaluasi siklus I yang meliputi penilaian aspek pengetahuan dimana mahasiswa harus menjawab soal UTS dan waktu yang tersisa digunakan untuk mengisi angket penilaian diri.

\section{c. Pengamatan}

Hasil penilaian observasi dan analisis hasil tes pada siklus I dapat di buat dalam beberapa kategori-kategori. Hasil penilaian sikap mahasiswa dapat di buat kategori seperti pada Gambar 1.

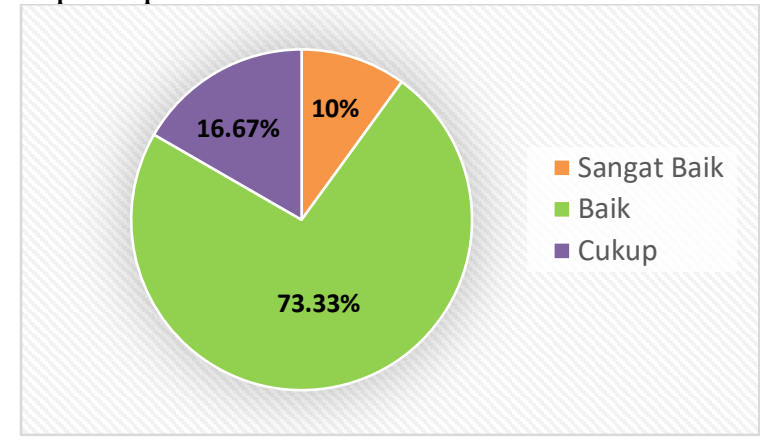

Gambar 1. Ketercapaian Aspek Sikap Mahasiswa Siklus I

Gambar 1 menunjukkan jika secara umum capaian aspek sikap mahasiswa sudah cukup baik hal itu ditunjukan dari jumlah mahasiswa sangat baik dan baik melampaui target minimal sebesar $75 \%$. Ada satu 
indikator sikap yaitu aspek jujur yang capaiannya masih di bawah target sehingga perlu dilanjutkan ke siklus II.

Hasil penilaian aspek pengetahuan bisa di lihat pada Gambar 2 berikut.

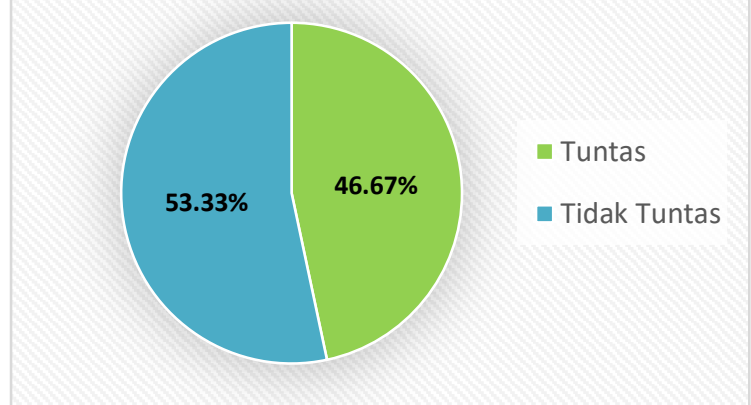

Gambar 2. Hasil Ketercapaian Aspek

Pengetahuan Mahasiswa Siklus I

Gambar 2 menunjukkan bahwa mahasiswa yang nilai yang tuntas masih di bawah target siklus I yaitu 75\%. Hasil siklus I terdapat dua indikator yang belum tuntas yaitu analisis harga satuan pekerjaan (AHSP) pekerjaan tanah dan analisis pengendalian kebutuhan waktu pekerjaan tanah, sehingga perlu dilanjutkan ke siklus II.

Hasil observasi menunjukkan penilaian aspek keterampilan seperti yang disajikan dalam Gambar 3.

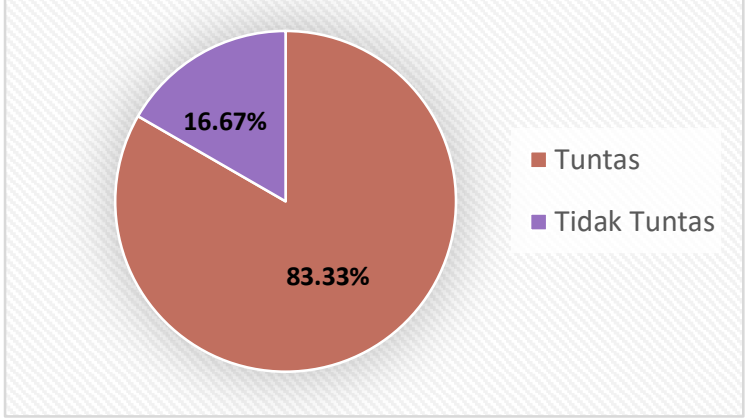

Gambar 3. Ketercapaian Aspek

Keterampilan Mahasiswa Siklus I

Pada penilaian aspek keterampilan, capaian mahasiswa yang tuntas sudah mencapai target siklus 1 yaitu sebesar $70 \%$. Semua indikator pada aspek ini sudah mencapai target yang direncanakan sehingga untuk penilaian aspek keterampilam hanya dilakukan pada siklus I.

Hasil angket dan observasi keaktifan mahasiswa dapat di lihat pada Gambar 4 berikut ini.

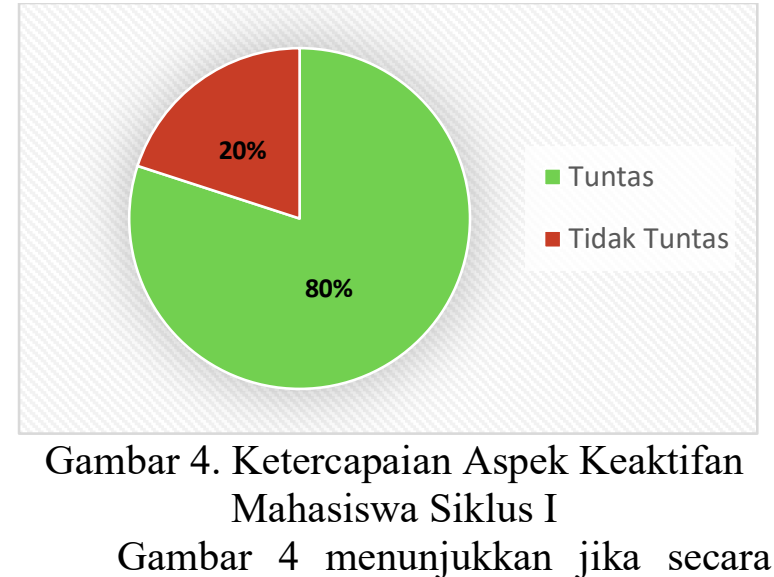
umum capaian aspek keaktifan mahasiswa sudah cukup baik hal itu ditunjukan dari jumlah mahasiswa tuntas yang sudah mencapai target siklus I sebesar $75 \%$, namun ada satu indikator keaktifan yaitu oral activity yang capaiannya masih di bawah target sehingga perlu dilanjutkan ke siklus II.

\section{d. Refleksi}

Hasil pengamatan yang dilakukan menunjukkan masih terdapat aspek yang belum mencapai target yaitu aspek pengetahuan, sikap dan keaktifan. Oleh karena itu, perlu dilaksanakan siklus II yang diharapkan dapat mencapai target yang sudah ditentukan.

\section{Siklus II}

\section{a. Perencanaan}

Pada pelaksanaan siklus II ini lebih difokuskan untuk perbaikan terhadap kendala-kendala yang muncul pada siklus I. Materi yang diberikan juga fokus pada indikator-indikator yang belum mencapai ketuntasan yaitu menentukan analisis harga satuan pekerjaan (AHSP) pekerjaan tanah dan analisis pengendalian kebutuhan waktu pekerjaan tanah.

Pemberian evaluasi juga terbatas pada soal dengan indikator-indikator yang belum tuntas saja. Dosen lebih memfokuskan pada mahasiswa yang hasil evaluasi siklus I mendapatkan nilai yang tergolong rendah dibandingkan teman-temannya untuk perbaikan pada siklus II.

Kelompok diskusi pada siklus II ini dibagi berdasarkan nilai yang telah di dapat 
mahasiswa pada evaluasi siklus I. Hal ini dilakukan agar mahasiswa yang sudah tuntas di siklus I dapat membantu temannya yang belum tuntas dalam satu kelompok tersebut bisa tuntas dalam evaluasi siklus II.

\section{b. Pelaksanaan}

Siklus II ini dilaksanakan dalam 2 kali pertemuan, yaitu 1 kali pertemuan untuk penyampaian materi dan 1 kali pertemuan untuk evaluasi siklus II.

Pada pertemuan pertama, dosen menjelaskan kepada mahasiswa bahwa pembelajaran ini lebih difokuskan kepada materi yang belum dipahami ada siklus I yaitu pada indikator analisis harga satuan pekerjaan (AHSP) pekerjaan tanah dan analisis pengendalian kebutuhan waktu pekerjaan tanah. Dosen memberikan soal diskusi agar mahasiswa lebih memahami materi yang diajarkan, setelah itu kelompok yang sudah selesai di minta maju untuk mengerjakan soal di depan dengan kelompok lain bisa bertanya terkait hal yang belum dimengerti. Dosen dan mahasiswa bersama membuat kesimpulan di akhir pembelajaran.

Pada pertemuan kedua atau pertemuan terakhir dilaksanakan evaluasi siklus II yang terdiri atas tes aspek pengetahuan berupa 15 soal objektif dan sisa waktunya digunakan ntuk mengisi angket penilaian diri.

\section{c. Pengamatan}

Hasil observasi dan analisis tes yang sudah dilakukan pada siklus II dapat di lihat dari hasil pada masing-masing aspek, yaitu aspek sikap, pengetahuan, dan keaktifan. Hasil observasi dan analisis angket aspek sikap mahasiswa dapat di lihat pada Gambar 5.

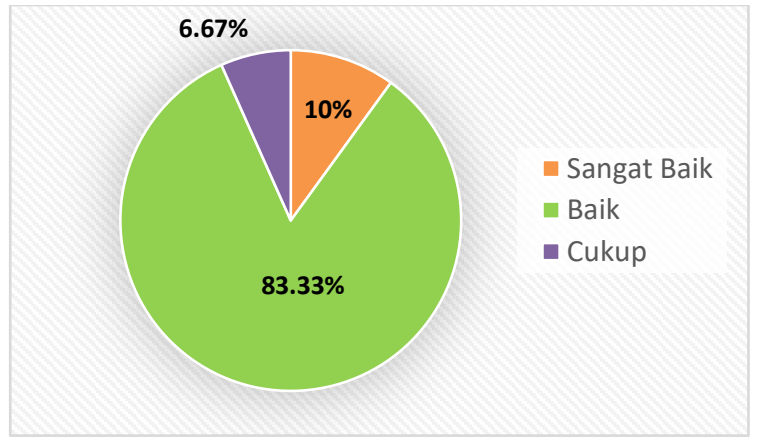

Gambar 5. Ketercapaian Aspek Sikap

Mahasiswa Siklus II

Hasil yang disajikan pada Gambar 5 menunjukkan capaian mahasiswa yang berkategori baik dan sangat baik sudah melampaui target yang direncanakan dan semua indikator juga sudah mencapai target sebesar 75\%, sehingga, penilaian aspek sikap dilakukan sampai siklus II ini.

Hasil tes aspek pengetahuan siklus II dapat di lihat pada Gambar 6.

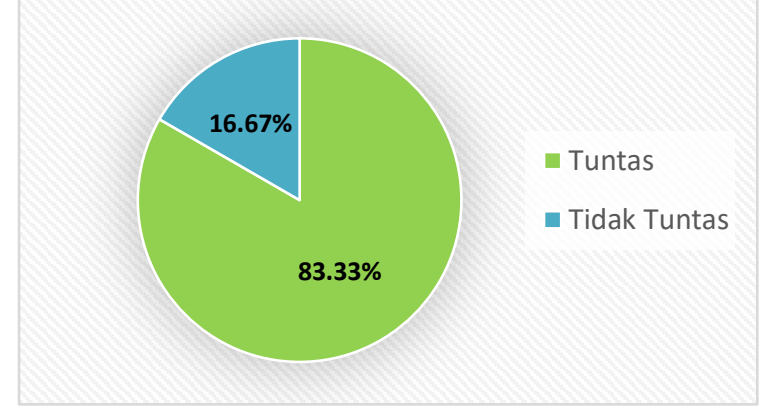

Gambar 6. Ketercapaian Aspek Pengetahuan Mahasiswa Siklus II

Jumlah capaian aspek pengetahuan siklus ini sebesar $83,33 \%$, hasil ini sudah melampaui target sebesar 75\%. Semua indikator pada siklus ini juga sudah mencapai target yang sudah direncanakan sehingga penilaian aspek pengetahuan mahasiswa diakhiri pada siklus II.

Hasil observasi dan analisis angket keaktifan mahasiswa dapat di lihat pada Gambar 7.

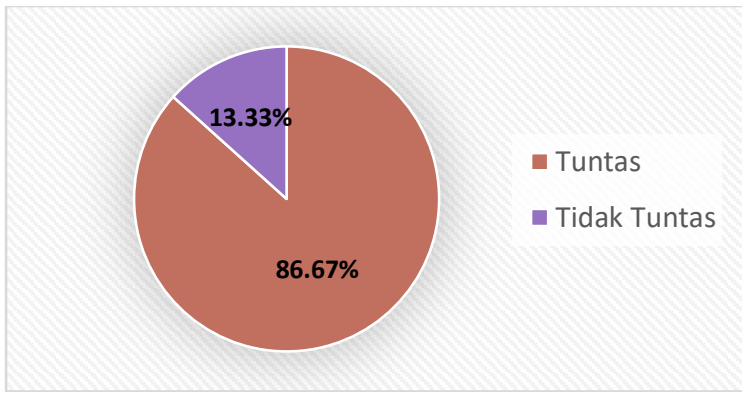

Gambar 7. Ketercapaian Aspek Keaktifan Mahasiswa Siklus II 
Gambar 7 menunjukkan jika secara umum capaian aspek keaktifan mahasiswa sudah cukup baik hal itu ditunjukan dari jumlah mahasiswa tuntas yang sudah mencapai target sebesar 75\%. Semua indikator pada aspek keaktifan juga sudah mencapai target sehingga penilaian aspek keaktifan diakhiri pada siklus II.

\section{d. Refleksi}

Berdasarkan data yang diperoleh pada siklus II, terlihat semua aspek meliputi aspek pengetahuan, sikap dan pertanyaan mengalami peningkatan capaian dan sudah melampaui target sehingga penelitian di akhiri pada siklus II.

\section{Pembahasan \\ Perbandingan Hasil 2 Siklus}

Berdasarkan hasil observasi, angket, tes dan wawancara yang telah dilakukan selama proses pembelajaran dengan model predict observe explain yang dilengkapi lembar kerja mahasiswa berbasis drill and practice diperoleh data bahwa model tersebut dapat meningkatkan keaktifan dan prestasi belajar pada materi analisis harga satuan pekerjaan (AHSP) pekerjaan tanah dan analisis pengendalian kebutuhan waktu pekerjaan tanah.

Keaktifan mahasiswa di nilai dari angket keaktifan yang diberikan pada akhir siklus. Observasi dan wawancara dilakukan sebagai pembanding untuk mengecek keabsahan data yang diperoleh. Keaktifan mahasiswa mengalami peningkatan dari siklus I ke siklus II sebesar 6,67\%. Hal ini disebabkan oleh dengan penggunaan model predict observe explain membuat mahasiswa mempunyai kesempatan yang lebih banyak untuk bertanya maupun mengungkapkan pendapatnya.

Mahasiswa juga menjadi lebih berani untuk menjawab pertanyaan dari dosen karena meningkatnya rasa percaya diri mereka. Melalui model predict observe explain mahasiswa dituntun untuk mengobservasi sendiri mengenai materi yang dipelajari, sehingga mahasiswa akan lebih lama mengingat konsep yang ada.
Pembelajaran dengan menggunakan model predict observe explain dapat meningkatkan kesempatan berharga siswa dalam mengkritik ide, menyampaikan pendapat dan mendukung perolehan pemahaman konseptual yang benar.

Variabel berikutnya dalam penelitian ini yaitu prestasi belajar yang meliputi aspek sikap, pengetahuan, dan keterampilan. Aspek sikap memiliki target sebesar $75 \%$ siswa tuntas. Sikap mahasiswa yang diamati yaitu spiritual, jujur, disiplin, tanggungjawab, dan kerjasama.

Cara penilaian aspek sikap yaitu dengan menggunakan modus atau nilai terbanyak. Kategori ketuntasan sikap terdiri dari sikap sangat baik dan sikap baik. Pada siklus I pencapaian aspek sikap sebesar $83,33 \%$. Hasil ini sudah memenuhi target yang telah ditentukan, namun pada pelaksanaan siklus II tetap dilakukan penilaian aspek sikap dikarenakan masih ada indikator yang belum tuntas yaitu aspek jujur. Hal ini dilakukan dengan tujuan untuk mengetahui apakah sikap mahasiswa mengalami peningkatan setelah adanya perbaikan pada proses pembelajaran.

Hasil data yang diperoleh pada siklus II mengalami peningkatan menjadi 93,33\%. Aspek kedua dalam prestasi belajar yaitu aspek pengetahuan. Pengamatan awal atau prasiklus pada penelitian ini dilakukan pada nilai ulangan harian materi analisis harga satuan pekerjaan (AHSP) pekerjaan tanah dan analisis pengendalian kebutuhan waktu pekerjaan tanah pada tahun akademik 2019/2020. Berdasarkan hasil kajian nilai tersebut diketahui bahwa ketuntasan materi analisis harga satuan pekerjaan (AHSP) pekerjaan tanah dan analisis pengendalian kebutuhan waktu pekerjaan tanah belum mencapai $50 \%$ mahasiswa tuntas. Target ketuntasan aspek pengetahuan pada penelitian ini yaitu $70 \%$.

Pada siklus I diperoleh ketuntasan aspek pengetahuan sebesar $46,67 \%$ atau sebanyak 14 mahasiswa tuntas. Hasil ini belum mencapai target yang ditentukan namun sudah mengalami peningkatan jika dibandingkan dengan tahun sebelumnya. 
Belum tuntasnya target pada siklus I ini dapat disebabkan karena mahasiswa belum terbiasa dengan penggunaan model pembelajaran predict observe explain, oleh karena itu pembelajaran dilanjutkan ke siklus II untuk meningkatkan hasil aspek pengetahuan.

Hasil tes siklus II menunjukkan $83,33 \%$ atau sebanyak 25 siswa telah mencapai kriteria ketuntasan minimum. Penggunaan model pembelajaran predict observe explain efektif dalam meningkatkan prestasi belajar mahasiswa. Hal ini berarti hasil aspek pengetahuan pada siklus II telah mencapai target. Kenaikan aspek pengetahuan dari pra-siklus ke siklus I dan siklus II dapat disebabkan oleh beberapa faktor, salah satunya yaitu perubahan kelompok yang terjadi pada siklus II. Mahasiswa yang memiliki keaktifan dan nilai yang tinggi pada siklus I di sebar merata ke dalam 8 kelompok. Mahasiswa yang memiliki keaktifan tinggi akan mendapatkan nilai pengetahuan yang tinggi. Hal ini disebabkan oleh mahasiswa yang rajin menulis hasil diskusi maka akan lebih mudah belajar dan apabila mahasiswa semakin sering bertanya maka mahasiswa akan semakin banyak memperoleh informasi baru yang belum diketahui sebelumnya.

Aspek terakhir pada prestasi belajar mahasiswa adalah keterampilan mahasiswa. Aspek ini di ukur dengan menggunakan praktik lapangan yang hanya dilakasanakan pada siklus I. Pelaksanaan praktik lapangan hanya dilakukan pada siklus I dikarenakan keterbatasan waktu yang diberikan oleh pihak kampus dalam melaksanakan praktik. Hasil pencapaian mahasiswa yang sudah melebihi target yang telah ditetapkan. Target yang ditetapkan pada aspek keterampilan adalah $70 \%$ dan pencapaian aspek keterampilan pada siklus I mencapai 83,33 $\%$.

Pencapaian pada setiap indikator juga sudah memenuhi target yang ditentukan. Hasil penilaian yang diperoleh pada siklus II menunjukkan bahwa penelitian tindakan kelas ini berhasil karena semua aspek yang di ukur telah mencapai target yang ditentukan. Peningkatan hasil dari siklus I ke siklus II ini disebabkan oleh: (1) adanya penguatan materi mengenai indikator yang belum tuntas sehingga mahasiswa dapat lebih memperdalam pengetahuannya; (2) guru lebih memfokuskan perhatian kepada mahasiswa yang mengalami kesulitan belajar dengan cara mendampingi dan memberikan penjelasan mengenai materi yang belum dipahami; dan (3) pengalaman mahasiswa pada siklus I sehingga pada pembelajaran siklus II mahasiswa sudah tidak bingung dan tidak banyak bertanya mengenai model pembelajaran predict observe explain yang digunakan.

Berdasarkan hasil tersebut, penelitian dengan menggunakan model pembelajaran predict observe explain dilengkapi dengan lembar kerja mahasiswa berbasis drill and practice dikatakan berhasil karena pada akhir penelitian semua aspek telah mencapai target yang ditetapkan. Penelitian ini dapat meningkatkan proses belajar mahasiswa yang berupa keaktifan serta prestasi belajar mahasiswa yang terdiri dari aspek sikap, aspek pengetahuan, dan aspek keterampilan.

\section{Simpulan}

Berdasarkan hasil penelitian yang telah dilakukan, maka dapat disimpulkan bahwa penerapan model pembelajaran predict observe explain dilengkapi lembar kerja mahasiswa berbasis drill and practice pada mata kuliah Pemindahan Tanah Mekanis, tahun akademik 2019/2020 dapat meningkatkan keaktifan dan prestasi belajar mahasiswa.

\section{Daftar Pustaka}

Dakhi, O., Jama, J., Irfan, D., Ambiyar, Ishak. (2020). Blended Learning: A 21 st Century Learning Model At College. International Journal Of Multi Science, 1(8), 50-65.

Fajra, M., Ambiyar, A., Rizal, F., \& Dakhi, O. (2020). Pengembangan Model Evaluasi Kualitas Output Pembelajaran Teknik Komputer dan Jaringan di SMK Kota Padang. Cakrawala: Jurnal Pendidikan, 14(1), 1-9. 
https://doi.org/10.24905/cakrawala.v1 $\underline{4 i 1.1480}$

Fajra, M., Jalinus, N., Jama, J., \& Dakhi, O. (2020). Model Pengembangan Kurikulum Sekolah Inklusi Berdasarkan Kebutuhan Perseorangan Anak Didik. Jurnal Pendidikan 21 (1), 51-63.

https://doi.org/10.33830/jp.v21i1.746. 2020

Ferdiansyah, Ambiyar, Zagoto, M. M., Putra, I E D., (2020). Pemanfaatan Media Pembelajaran berbasis E Learning dalam Meningkatkan Hasil Belajar pada Matakuliah Media Pembelajaran Musik. Komposisi: Jurnal Pendidikan Bahasa, Sastra, dan Seni, 21(1), 062-072. DOI: https://doi.org/10.24036/komposisi.v2 1 i1 108082

Masril, M., Dakhi, O., Nasution, T., Ambiyar. (2020). Analisis Gender Dan Intellectual Intelligence Terhadap Kreativitas. Edukasi: Jurnal Pendidikan, 18 (2), 182-191. https://doi.org/10.31571/edukasi.v18i2 .1847

Masril, M., Jalinus, N., Jama, J., \& Dakhi, O. (2020). Implementasi Pembelajaran Berbasis Masalah Pada Kurikulum 2013 Di SMK Negeri 2 Padang. Konstruktivisme: Jurnal Pendidikan Dan Pembelajaran , 12 (1), 12-25.

Muna, I. Aliyatul. 2017. Model Pembelajaran Poe (Predict Observe Explain) Dalam Meningkatkan Pemahaman Konsep Dan Keterampilan Proses IPA ElWasathiya. Jurnal Studi Agama Volume 5, Nomor 1, Juni 2017; pISSN 2338-9648, e-ISSN: 2527631X.

Pujawan, Kadek Agus Hendra (2018). "The Development of Interactive Multimedia with Drill and Practice Model on Media Ii ( Two Dimention Animation) Course in Politeknik
Ganesha Guru," journal of Education Research and Evaluation 2, No. 1.

Rina Novalinda, Oskah Dakhi, Melda Fajra, Azmil Azman, Mardhiah Masril, Ambiyar,Unung Verawadina (2020). Learning Model Team Assisted Individualization Assisted Module to Improve Social Interaction and Student Learning Achievement. Universal Journal of Educational Research, 8(12A), 7974 -7980. DOI: 10.13189/ujer.2020.082585.

Sugiyono (2018). Metode Penelitian Kuantitatif, Kualitatif, dan $R \& D$. Bandung: Alfabeta.

Sumirat, Fany. 2012. Efektifitas Model Predict, Observe, Explain untuk Meningkatkan Keterampilan Berpikir Kritis dan Memfasilitasi Perubahan Konseptual Siswa Sekolah Dasar. Skripsi. Universitas Pendidikan Indonesia

Telaumbanua, A., Dakhi, O., \& Zagoto, M. M. (2021). Penerapan Model Pembelajaran Group Investigation Berbantuan Modul Pada Mata Kuliah Praktek Kayu. Edumaspul: Jurnal Pendidikan, 5(2), 839-847. Retrieved from https://ummaspul.ejournal.id/maspuljr/article/view/2558

Timor, A. R., Ambiyar, A., Dakhi, O., Verawardina, U., \& Zagoto, M. M. (2020). Effectiveness of problembased model learning on learning outcomes and student learning motivation in basic electronic subjects. International journal of multi science, 1(10), 1-8

Udayani, K.M, dkk. 2016. Penerapan Model Pembelajaran Predict- ObserveExplain (POE) Untuk Meningkatkan Hasil Belajar IPA Siswa. e-Journal $P G S D$ Universitas pendidikan Ganesha Jurusan PGSD, Vol: 4 No: 1 Tahun: 2016.

Widyaningrum, Ratna, dkk. 2013. Pengembangan Modul Berorientasi 
Jurnal Edumaspul, 5 (2), Year 2021 - 881

(Yelisman Zebua, Maria Magdalena Zagoto, Oskah Dakhi)

POE (Predict, Observe, Explain) Berwawasan Lingkungan Pada Materi Pencemaran Untuk Meningkatkan Hasil Belajar Siswa. Bioedukasi, Volume 6, Nomor 1 Halaman 100117.

Zagoto, Maria M., Yarni, Nevi; Dakhi, O. (2019). Perbedaan Individu dari Gaya Belajarnya Serta Implikasinya Dalam Pembelajaran. Jurnal Review Pendidikan dan Pengajaran, 2(2), 259-265.

Zagoto, Maria M. \& Dakhi, O (2018). Pengembangan

Perangkat

Pembelajaran Matematika Peminatan Berbasis Pendekatan Saintifik Untuk Siswa Kelas XI Sekolah Menengah Atas. Jurnal Review Pendidikan dan Pengajaran, 1(1), 157-170.

Zebua, Y (2020). Media Powerpoint Berbasis Video Terhadap Hasil Belajar Materi Keselamatan Dan Kesehatan Kerja (K3) Pada Mahasiswa Pendidikan Teknik Bangunan Ikip Gunungsitoli. Jurnal Review Pendidikan dan Pengajaran, Volume 3Nomor 2, hal 469-475. DOI: https://doi.org/10.31004/jrpp.v3i2.170 $\underline{1}$

Zebua, Y (2021). Kesiapan Pelaksanaan Praktik Kerja Industri Program Studi Pendidikan Teknik Bangunan Ikip Gunungsitoli. Jurnal Review Pendidikan dan Pengajaran, Vol. 4 No. 1, hal 216-220. DOI: https://doi.org/10.31004/jrpp.v4i1.214 4

Zega, A., Zagoto, M., \& Dakhi, O. (2021). Implementasi Model Guided Inquiry Berbantuan Media Pembelajaran SketchUp Pada Mata Kuliah Konstruksi Bangunan. Edumaspul:
Jurnal Pendidikan, 5(2), 831-838. https://doi.org/10.33487/edumaspul.v5 i2.2464

\section{Profil Penulis 1}

Yelisman Zebua, S.Pd., M.Pd.T. Lahir pada 28 Agustus 1983. Penulis adalah dosen tetap di Prodi Pendidikan Teknik Bangunan, Fakultas Pendidikan Teknologi dan Kejuruan (FPTK), IKIP Gunungsitoli, Sumatera Utara. Penulis Lulus S1 pada tahun 2010 pada Program Studi Pendidikan Teknik Bangunan, IKIP Gunungsitoli, dan Lulus S2 pada tahun 2016 pada Program studi Pendidikan Teknologi dan Kejuruan Keahlian Pendidikan Teknik Bangunan, Universitas Negeri Padang.

\section{Profil Penulis 2}

Maria Magdalena Zagoto. Lahir pada 29 September 1991. Penulis adalah dosen tetap di Prodi Pendidikan Matematika, FKIP, Universitas Nias Raya, Sumatera Utara. Penulis adalah mahasiswa program Doctoral (S3) pada Fakultas Ilmu Pendidikan, Universitas Negeri Padang, Sumatera Barat. Penulis Lulus S1 pada tahun 2013 pada Program Studi Pendidikan Matematika, STKIP Nias Selatan. dan Lulus S2 pada tahun 2016 pada Program Pendidikan Matematika, Universitas Negeri Padang.

\section{Profil Penulis 3}

Oskah Dakhi, Lahir pada 17 Pebruari 1989. Penulis adalah mahasiswa program Doctoral (S3) pada Fakultas Teknik Pendidikan Teknologi dan Kejuruan, Universitas Negeri Padang, Sumatera Barat. Penulis Lulus S1 pada tahun 2012 pada Program Studi Teknik Informatika, STMIK Budidarma Medan. dan Lulus S2 pada tahun 2014 pada Program studi Ilmu Komputer, UPI, YPTK Padang. 